\title{
Effect of insulin or insulin-like growth factor-I administration at mid-luteal phase of the estrous cycle during superovulation on hormonal profile of Sahiwal cows
}

\author{
S. K. Sheetal, Shiv Prasad and H. P. Gupta
}

\begin{abstract}
Department of Veterinary Gynaecology and Obstetrics, College of Veterinary and Animal Sciences, Govind Ballabh Pant University of Agriculture and Technology, Pantnagar, Uttarakhand, India.

Corresponding author: S. K. Sheetal, e-mail: sksheetalmuz@gmail.com

Co-authors: SP: shivp2003@yahoo.co.uk, HPG: hpguptavgo@gmail.com

Received: 30-07-2018, Accepted: 13-11-2018, Published online: 28-12-2018
\end{abstract}

doi: 10.14202/vetworld.2018.1736-1741 How to cite this article: Sheetal SK, Prasad S, Gupta HP (2018) Effect of insulin or insulin-like growth factor-I administration at mid-luteal phase of the estrous cycle during superovulation on hormonal profile of Sahiwal cows, Veterinary World, 11(12): 1736-1741.

\begin{abstract}
Aim: The present study was designed to study the effect of insulin and insulin-like growth factor-1 (IGF-I) administration during luteal phase of the estrous cycle on the hormonal profile of Sahiwal embryo donor cows during superovulation.

Materials and Methods: Cows $(n=18)$ were selected and divided into three groups; control $(n=6$, untreated), T-I ( $n=6$, insulin-treated), and T-II ( $\mathrm{n}=6$, IGF-I treated). Insulin and IGF-I were given S/C on $5^{\text {th }}, 6^{\text {th }}, 7^{\text {th }}$, and $8^{\text {th }}$ days of estrous cycle. Superovulatory treatment was started on day $9^{\text {th }}$ of the estrous cycle. With the sixth dose of follicle-stimulating hormone, prostaglandin was injected to induce superovulatory heat. The superovulated cows were bred, and superovulatory response of each animal was recorded. The embryos were collected non-surgically on the $7^{\text {th }}$ day of superovulatory estrus. About $15 \mathrm{ml}$ blood without anticoagulant was collected on days $5,7,9,11,13,15,17,19$, and 21 or day of embryo recovery where day 0 of estrous cycle was taken as day of estrus. Serum was separated, centrifuged, and transferred into sterilized serum vials. All samples were stored at $-20^{\circ} \mathrm{C}$ till analysis. Progesterone, insulin, and IGF-I were estimated in blood serum by radioimmunoassay using radioimmunoassay kits.
\end{abstract}

Results and Discussion: The mean concentration of progesterone on days 7 and 11, insulin on days 7 and 9, and IGF-I on days $5,7,9,11$, and 15 was significantly higher in insulin-treated T-I groups as compared to untreated control.

Conclusion: It may be concluded that exogenous insulin administration during mid-luteal phase may be helpful in follicular and embryonic development through modulation of progesterone, insulin, and IGF-I in indigenous (Bos indicus) Sahiwal embryo donor cows.

Keywords: insulin-like growth factor-1, insulin, progesterone, Sahiwal, superovulation.

\section{Introduction}

Bovine embryo transfer technology is being widely used around the world for the production of breeding stock. The semen produced from such elite bulls is disseminated for livestock improvement. In this technique, genetic contribution of both the male and female is utilized simultaneously leading to faster genetic improvement. In India and other Asian countries, the demand to multiply the genetic material of valuable Bos indicus females has increased. Sahiwal cow is one of them which is more suitable to our climatic conditions as compared to Bos taurus. However, poor superovulatory response, inappropriate storage, and higher embryo mortality leading to lower conception rate in recipient are some of the major problems that limit field application in large scale.

Copyright: Sheetal, et al. Open Access. This article is distributed under the terms of the Creative Commons Attribution 4.0 International License (http://creativecommons.org/licenses/ by/4.0/), which permits unrestricted use, distribution, and reproduction in any medium, provided you give appropriate credit to the original author(s) and the source, provide a link to the Creative Commons license, and indicate if changes were made. The Creative Commons Public Domain Dedication waiver (http:// creativecommons.org/publicdomain/zero/1.0/) applies to the data made available in this article, unless otherwise stated.
Insulin application to modulate the reproduction is a recent development. In vitro studies revealed insulin and insulin-like growth factor-1 (IGF-I) as important mediators of follicular development, steroidogenesis, oocyte maturation, and subsequent embryo development [1]. Administration of insulin increases intrafollicular and peripheral IGF-I levels in cattle [2] and positively correlated with the peripheral concentration of insulin and IGF-I [3]. Hence, the use of insulin may be considered as an alternative approach to improve superovulatory response.

IGF-1 of endocrine origin has been positively linked to the reproductive performance of cow $[4,5]$ and ewes [6]. Future fertility of cows [7] and the timing of first and postpartum ovulations in dairy cows [8] can be predicted by measuring the circulating IGF-1 level. However, the efficacy of IGF-1 administration and their level in the blood to forecast the success of MOET/SOET programs in cattle is poor. These metabolic hormones influence the superovulatory response by increasing the population of gonadotrophin-dependent follicles.

Thus, the present work was designed to study the effect of insulin and IGF-I treatment on alteration in hormonal profile in embryo donor Sahiwal cows. 


\section{Materials and Methods}

\section{Ethical approval}

The present investigation was carried out after the approval of the Institutional Animal Ethics Committee.

\section{Study design}

It was designed to study the effect of insulin and IGF-I administration during the mid-luteal phase of the estrous cycle on the hormonal profile of Sahiwal donor cows. For embryo donor, Sahiwal cows $(n=18)$ were selected and divided into three groups; control ( $n=6$, untreated), T-I ( $n=6$, insulin-treated), and T-II $(n=6, I G F-I$ treated). The sample size was only 18 because superior qualities of cows were selected based on per-rectal examination of herd. Further, the cost of superovulation and embryo transfer is very high due to the higher price of follicle-stimulating hormone (FSH) (Folltropin-V), which limits our sample size. However, this sample size was enough for statistical analysis. Insulin was given at $0.25 \mathrm{IU} / \mathrm{kg}$ body weight by $\mathrm{S} / \mathrm{C}$ to the animals of the treatment Group I, on $5^{\text {th }}, 6^{\text {th }}, 7^{\text {th }}$, and $8^{\text {th }}$ days of the estrous cycle. IGF-I was given at $10 \mu \mathrm{g}$ total dose per day by $\mathrm{S} / \mathrm{C}$ to the animals of the treatment Group II, on $5^{\text {th }}, 6^{\text {th }}, 7^{\text {th }}$, and $8^{\text {th }}$ days of estrous cycle. Superovulatory treatment was started on day $9^{\text {th }}$ after the onset of standing estrus (Folltropin-V, Vetoquinol, Canada, $30 \mathrm{mg}$ twice daily at $12 \mathrm{~h}$ intervals for 4 days, and total dose $240 \mathrm{mg}$ in 8 divided doses). With the sixth dose of FSH, prostaglandin (PGF) was injected to induce superovulatory heat. The superovulated cows were bred 2 times at $12 \mathrm{~h}$ interval through artificial insemination using good quality frozen semen, and superovulatory response of each animal was recorded based on a total number of corpus luteum (CL) and unovulatory follicles present, with the help of per-rectal examination and sonography of both ovaries. The embryos were collected non-surgically on the $7^{\text {th }}$ day of superovulatory estrus. About $15 \mathrm{ml}$ blood without anticoagulant was collected on days $5,7,9,11,13,15,17,19$, and 21 where day 0 of estrous cycle was taken as day of estrus. The days 9, 11, 13, and 21 correspond to day of the initiation of FSH treatment, day of PGF2 $\alpha$ injection, day of superovulatory estrus, and day of embryo recovery, respectively. The sterilized test tube kept at room temperature as a slant for $1 \mathrm{~h}$ for separation of blood serum. Serum was separated, centrifuged at $3000 \mathrm{rpm}$ for $15 \mathrm{~min}$, and transferred into sterilized serum vials. All samples were stored at $-20^{\circ} \mathrm{C}$ until analysis.

\section{Hormonal estimation}

Progesterone, insulin, and IGF-I were estimated in blood serum by radioimmunoassay (RIA) using RIA kits (M/S Beckman Coulter IM 1188). The progesterone estimation (analytical sensitivity: $0.03 \mathrm{ng} / \mathrm{mL}$ or $0.10 \mathrm{nmol} / \mathrm{L}$ ) in plasma samples was done using progesterone C.T. RIA kit. The insulin estimation (analytical sensitivity: $0.49 \mu \mathrm{IU} / \mathrm{mL}$ ) in serum samples was done using insulin(e) IRMA kit. The IGF-I estimation (Analytical sensitivity: $4.55 \mathrm{ng} / \mathrm{mL}$ ) in serum samples was done using IGF-I IRMA kit at IVRI (Nuclear Research Laboratory under Division of Physiology and Climatology).

\section{Statistical analysis}

The data were analyzed statistically using analysis of variance [9]. The analysis of data was applied both within the group and between the groups for the concentrations of progesterone, insulin and insulin like growth factor-I (IGF-I). Differences were considered significant at $\mathrm{p}<0.05$ and $\mathrm{p}<0.01$.

\section{Results \\ Progesterone}

The mean serum progesterone concentration at different phases of the estrous cycle in control, T-I (insulin-treated), and T-II (IGF-I treated) groups have been presented in Table-1 and Figure-1. Its concentration on day $5^{\text {th }}$ of estrous cycle did not differ significantly among the groups. On day 7 , there is a significant difference found between control and T-I (insulin-treated) groups. Further, its concentration on the $9^{\text {th }}$ day, that is, day of initiation of FSH treatment differs non-significantly $(\mathrm{p}>0.05)$ but higher in T-I and T-II than the control group. The levels of

Table-1: Serum progesterone concentration $(\mathrm{ng} / \mathrm{ml})$ of different groups on different days of estrous cycle/ superovulatory treatment of Sahiwal donors.

\begin{tabular}{|c|c|c|c|}
\hline \multirow{2}{*}{$\begin{array}{l}\text { Days of } \\
\text { estrous cycle }\end{array}$} & \multicolumn{3}{|c|}{ Groups } \\
\hline & Control $(n=6)$ & $\begin{array}{c}\text { T-I } \\
(\mathrm{n}=6 \text {, insulin at } 0.25 \mathrm{IU} / \mathrm{kg} \text { b. wt. S/C) }\end{array}$ & $\begin{array}{c}\text { T-II } \\
(\mathrm{n}=6, \text { IGF-I at } 10 \mu \mathrm{g} \text { total dose per day S/C) }\end{array}$ \\
\hline Day 5 & $1.73 \pm 0.29 \mathrm{ba}$ & $2.54 \pm 0.23^{\text {ba }}$ & $1.80 \pm 0.23^{a}$ \\
\hline Day 7 & $2.49 \pm 0.59^{\mathrm{baA}}$ & $4.36 \pm 0.25^{\mathrm{baB}}$ & $2.85 \pm 0.55^{\mathrm{aBA}}$ \\
\hline Day 9 & $3.24 \pm 0.69^{\mathrm{ba}}$ & $5.55 \pm 0.41^{\mathrm{ba}}$ & $4.60 \pm 0.84^{a}$ \\
\hline Day 11 & $3.35 \pm 0.58^{\mathrm{baA}}$ & $5.62 \pm 0.52^{\mathrm{baB}}$ & $4.98 \pm 0.49^{\mathrm{aBA}}$ \\
\hline Day 13 & $0.69 \pm 0.04^{a}$ & $0.71 \pm 0.07^{a}$ & $0.76 \pm 0.07^{a}$ \\
\hline Day 15 & $1.22 \pm 0.28^{\mathrm{ba}}$ & $1.55 \pm 0.30^{\mathrm{a}}$ & $1.51 \pm 0.29^{a}$ \\
\hline Day 17 & $9.71 \pm 1.93^{\mathrm{cb}}$ & $10.05 \pm 1.85^{b}$ & $10.21 \pm 2.34^{a}$ \\
\hline Day 19 & $17.73 \pm 2.09^{d c}$ & $19.50 \pm 0.58^{c}$ & $22.46 \pm 3.03^{b}$ \\
\hline Day 21 or DER & $23.46 \pm 4.70^{d}$ & $32.85 \pm 4.45^{d}$ & $27.50 \pm 5.40^{b}$ \\
\hline
\end{tabular}

(Means bearing different superscripts differed significantly $(p<0.05)$ within the groups $(a, b, c, d)$ and between the groups (A, B). IGF-I=Insulin-like growth factor-I 
progesterone remained constant at day $9^{\text {th }}$ and $11^{\text {th }}$ as functional CL were present on ovary of each cow. The concentration of serum progesterone declined significantly following PGF2 $\alpha$ injection in all the groups and reached its basal level on the day of superovulatory estrus $(<1 \mathrm{ng} / \mathrm{ml})$ in all the groups. Its concentration increased in all groups following superovulatory estrous, that is, from $13^{\text {th }}$ day to $21^{\text {st }}$ or day of embryo recovery. The peak value of progesterone reached on the day of embryo recovery, and the highest value was found in T-I group.

\section{Insulin}

The mean serum insulin concentration during different phases of the estrous cycle in control, T-I (insulin-treated), and T-II (IGF-I treated) groups have been presented in Table-2 and Figure-2. Its concentration on days 7 and 9 differs significantly $(p<0.05)$ between control and T-I groups. The concentration of insulin on the $9^{\text {th }}$ day, that is, day of initiation of FSH treatment was significantly $(\mathrm{p}<0.05)$ higher in T-I than the control group (Table-2). Its concentration further increased on the $11^{\text {th }}$ day in control and T-I groups but increase over a $9^{\text {th }}$ day in these groups was non-significant. The mean insulin concentration started declining following PGF $2 \alpha$ injection on $11^{\text {th }}$ day in all the three groups and reached lowest on the day 13 i.e., day of superovulatory estrus and differed non-significantly within groups $(p>0.05)$. The mean insulin concentration further increased in all groups from $13^{\text {th }}$ day to $21^{\text {st }}$ or day of embryo recovery (DER). The peak value of insulin was recorded on the $21^{\text {st }}$ day or DER in all groups and differs significantly from $13^{\text {th }}$ day in control, and the highest value was found in T-I group.

\section{IGF-I}

The mean serum IGF-I concentration at different phases of the estrous cycle in control, T-I (insulin-treated), and T-II (IGF-I treated) groups have been presented in Table-3 and Figure-3. Its concentration on day $5^{\text {th }}$ differs significantly $(\mathrm{p}<0.05)$ in T-I and T-II groups from control, on $7^{\text {th }}, 9^{\text {th }}$, and $11^{\text {th }}$ days T-I from control and T-II, on $15^{\text {th }}$ day significant from each other, and on $19^{\text {th }}$ day between T-I and T-II $(\mathrm{p}<0.05)$.
The concentration of IGF-I on the $9^{\text {th }}$ day, that is, day of initiation of FSH treatment was higher in T-I than T-II and control groups. The mean concentration of IGF-I further increased continuously from $11^{\text {th }}$ day to $21^{\text {st }}$ day in the control group (Table-3). The concentration of IGF-I slightly decreased on the $13^{\text {th }}$ day in T-I group and $15^{\text {th }}$ day in T-II group, then increased continuously up to a $21^{\text {st }}$ day. The mean IGF-I concentration started declining following PGF2 $\alpha$ injection on $11^{\text {th }}$ day in T-I group and reached lowest on the day 13 i.e., day of superovulatory estrus which differ

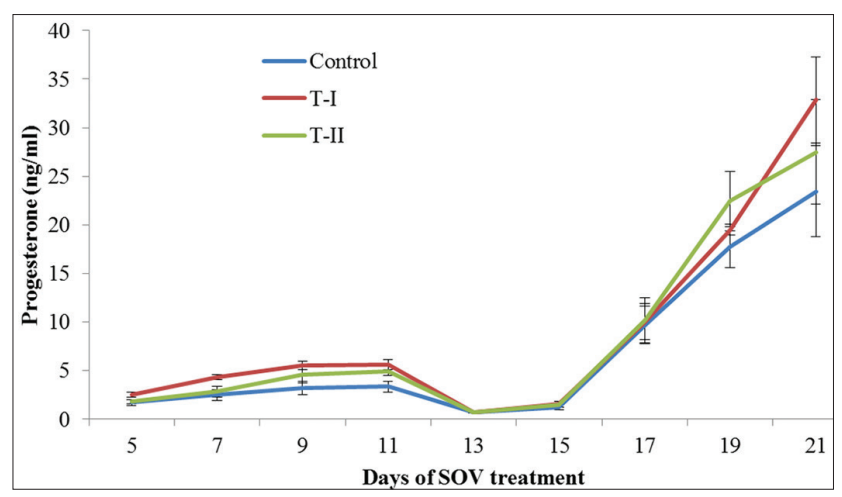

Figure-1: Mean ( \pm standard error) serum progesterone concentration $(\mathrm{ng} / \mathrm{ml})$ of different groups on different days of estrous cycle/superovulatory treatment of Sahiwal donors.

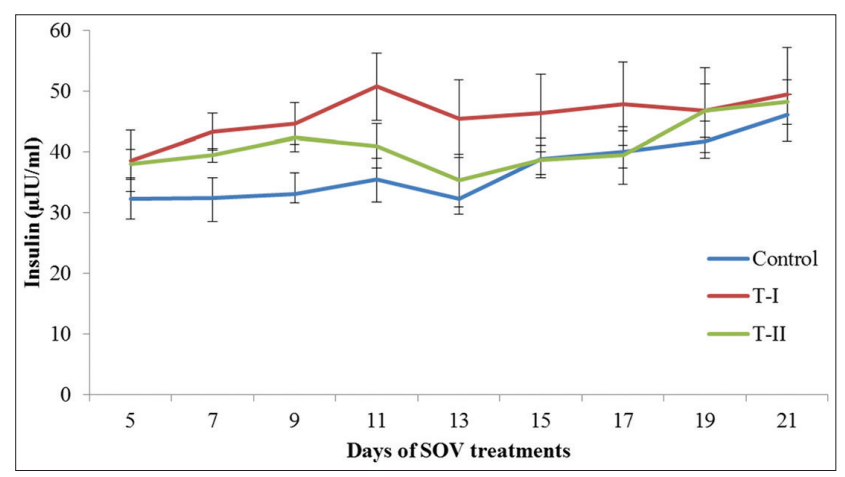

Figure-2: Mean ( \pm standard error) serum insulin concentration $(\mu \mathrm{IU} / \mathrm{ml})$ of different groups on different days of estrous cycle/superovulatory treatment of Sahiwal donors.

Table-2: Serum insulin concentration ( $\mu \mathrm{IU} / \mathrm{ml}$ ) of different groups on different days of estrous cycle/superovulatory treatment of Sahiwal donors.

\begin{tabular}{|c|c|c|c|}
\hline \multirow{2}{*}{$\begin{array}{l}\text { Days of the } \\
\text { estrous cycle }\end{array}$} & \multicolumn{3}{|c|}{ Groups } \\
\hline & Control $(n=6)$ & $\begin{array}{c}\text { T-I } \\
(\mathrm{n}=6, \text { insulin at } 0.25 \mathrm{IU} / \mathrm{kg} \text { b. wt. S/C) }\end{array}$ & $\begin{array}{c}\text { T-II } \\
(\mathrm{n}=6, \mathrm{IGF}-\mathrm{I} \text { at } 10 \mu \mathrm{g} \text { total dose per day } \mathrm{S} / \mathrm{C})\end{array}$ \\
\hline Day 5 & $32.32 \pm 3.41^{a}$ & $38.53 \pm 5.04$ & $37.94 \pm 2.51$ \\
\hline Day 7 & $32.38 \pm 3.85^{\mathrm{aA}}$ & $43.31 \pm 3.04^{B}$ & $39.43 \pm 1.17^{\mathrm{BA}}$ \\
\hline Day 9 & $33.12 \pm 1.54^{\mathrm{baA}}$ & $44.63 \pm 3.46^{B}$ & $42.37 \pm 2.43^{\mathrm{BA}}$ \\
\hline Day 11 & $35.51 \pm 3.77^{\text {ba }}$ & $50.75 \pm 5.57$ & $41.00 \pm 3.68$ \\
\hline Day 13 & $32.23 \pm 2.54^{a}$ & $45.48 \pm 6.39$ & $35.29 \pm 4.37$ \\
\hline Day 15 & $38.81 \pm 3.1^{\text {ba }}$ & $46.41 \pm 6.37$ & $38.71 \pm 2.4$ \\
\hline Day 17 & $40.01 \pm 2.62^{\mathrm{ba}}$ & $47.92 \pm 6.83$ & $39.44 \pm 4.73$ \\
\hline Day 19 & $41.69 \pm 2.69^{\mathrm{ba}}$ & $46.82 \pm 7.00$ & $46.77 \pm 4.38$ \\
\hline Day 21 or DER & $46.11 \pm 1.57^{b}$ & $49.42 \pm 7.71$ & $48.22 \pm 3.68$ \\
\hline
\end{tabular}

Means bearing different superscripts differed significantly $(p<0.05)$ within the groups $(a, b, c, d)$ and between the groups (A, B). IGF=Insulin-like growth factor-1 
Table-3: Serum IGF-I concentration $(\mathrm{ng} / \mathrm{ml}$ ) of different groups on different days of estrous cycle/superovulatory treatment of Sahiwal donors.

\begin{tabular}{|c|c|c|c|}
\hline \multirow{2}{*}{$\begin{array}{l}\text { Days of the } \\
\text { estrous cycle }\end{array}$} & \multicolumn{3}{|c|}{ Groups } \\
\hline & Control $(n=6)$ & $\begin{array}{c}\text { T-I } \\
\text { ( } \mathrm{n}=6 \text {, insulin at } 0.25 \mathrm{IU} / \mathrm{kg} \text { b. wt. } \mathrm{S} / \mathrm{C})\end{array}$ & $\begin{array}{c}\text { T-II } \\
(\mathrm{n}=6, \text { IGF-I at } 10 \mu \mathrm{g} \text { total dose per day S/C) }\end{array}$ \\
\hline Day 5 & $52.14 \pm 3.19^{\mathrm{aA}}$ & $95.86 \pm 8.32^{\mathrm{aB}}$ & $80.3 \pm 3.48^{\mathrm{baB}}$ \\
\hline Day 7 & $74.62 \pm 6.58^{\mathrm{baA}}$ & $104.7 \pm 9.10^{\text {вав }}$ & $78.65 \pm 2.80^{\mathrm{baA}}$ \\
\hline Day 9 & $79.40 \pm 6.09^{\mathrm{baA}}$ & $127.49 \pm 5.91^{\mathrm{cbaB}}$ & $86.26 \pm 7.25^{\mathrm{baA}}$ \\
\hline Day 11 & $80.42 \pm 9.82^{\mathrm{baA}}$ & $130.16 \pm 2.26^{\mathrm{cbaB}}$ & $94.35 \pm 2.09^{\mathrm{baA}}$ \\
\hline Day 13 & $106.00 \pm 14.15^{b}$ & $121.57 \pm 11.47^{\mathrm{cba}}$ & $111.82 \pm 11.70^{b}$ \\
\hline Day 15 & $107.15 \pm 11.24^{\mathrm{bB}}$ & $138.15 \pm 5.25^{\mathrm{cbac}}$ & $74.28 \pm 3.97^{\mathrm{aA}}$ \\
\hline Day 17 & $118.65 \pm 16.11^{b}$ & $140.02 \pm 4.41^{\mathrm{cb}}$ & $95.92 \pm 12.57^{\text {ba }}$ \\
\hline Day 19 & $119.45 \pm 12.30^{\mathrm{bBA}}$ & $147.25 \pm 14.97^{\mathrm{CB}}$ & $97.61 \pm 7.10^{\mathrm{baA}}$ \\
\hline Day 21 or DER & $125.8 \pm 14.87^{b}$ & $151.02 \pm 12.88^{c}$ & $112.24 \pm 8.76^{b}$ \\
\hline
\end{tabular}

Means bearing different superscripts differed significantly $(p<0.05)$ within the groups $(a, b, c, d)$ and between the groups (A, B). IGF-I=Insulin-like growth factor-1

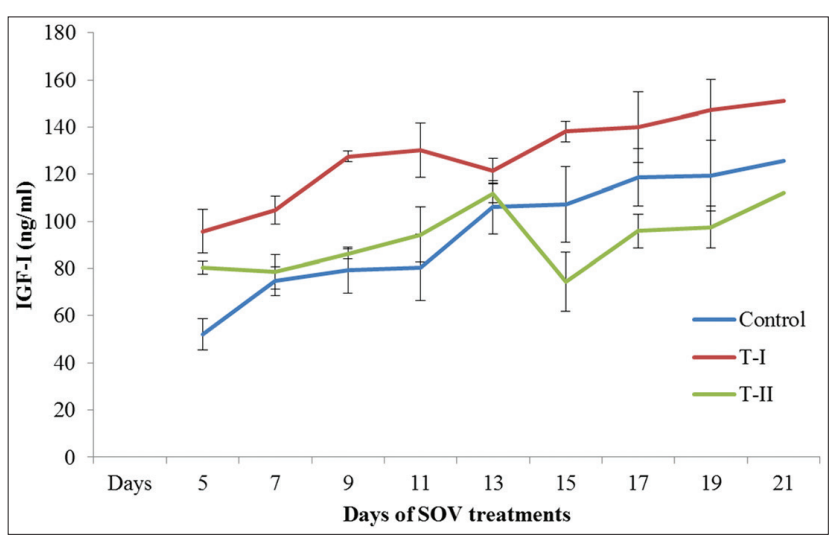

Figure-3: Mean ( \pm standard error) serum insulin-like growth factor-1 concentration $(\mathrm{ng} / \mathrm{ml})$ of different groups on different days of estrous cycle/superovulatory treatment of Sahiwal donors.

non-significantly ( $>>0.05)$ within groups.

\section{Discussion}

The mean concentration of serum progesterone on day 5 of estrous cycle is in agreement with Pandey et al. [10], who reported values of progesterone $<2 \mathrm{ng} / \mathrm{ml}$ on this day. Its concentration on the $9^{\text {th }}$ day differs non-significantly but higher in T-I and T-II than control group. These findings are in agreement with the reports of Shukla et al. [11] and Gupta et al. [12], who reported that exogenous insulin is luteotrophic in nature which increases the serum concentration of progesterone. The higher progesterone levels at second follicular wave lead to more follicular recruitment during superovulatory treatment, which yields more embryos at the day of recovery [13]. The population of medium-sized antral follicles has been reported to be more during 9-13 days of cycle or during CL dominance or at a higher level of progesterone. Thus, follicles recruited more if superovulatory treatment started at a higher level of progesterone. The levels of progesterone remained constant at days $9^{\text {th }}$ and $11^{\text {th }}$ as functional CL was present on the ovary of each cow. The progesterone declined significantly following PGF2 $\alpha$ injection in all the groups and reached its basal level on the day of superovulatory estrus $(<1 \mathrm{ng} / \mathrm{ml})$. Similar finding was reported by Siddiqui et al. [14]. At this time, progesterone level was the lowest of all stages due to induced luteolysis. The mean progesterone concentration increased in all groups following superovulatory estrous to day of embryo recovery and the peak value reached on the day of embryo recovery. The peak value on the day of embryo recovery in T-I group might be due to more number of CL formed after ovulations. These findings are in agreement with the many workers $[15,16]$, who reported that progesterone concentration on days 3-4 post superovulatory estrus up to the day of embryo recovery was higher with the more numbers of CL. The value of progesterone on the day of embryo recovery in this study was much higher than that reported by Siddiqui et al. [14] in Sahiwal cows and heifers.

The mean concentration of serum insulin increased in all groups, but on days $7^{\text {th }}$ and $9^{\text {th }}$ difference was significantly higher between control and T-I groups. These findings are in agreement with the reports of Selvaraju et al. [17] in repeat breeding cows and Souza et al. [18] in goats. It is found that the administration of insulin significantly increased the insulin levels in goats [18] during superovulation. They also found that when insulin was injected before mating, a strong relationship between ovulations and number of transferable embryos was found. However, it has been shown that feeding regimens which increase insulin (hyperinsulinemia) stimulate follicular growth and increase follicular recruitment in heifers [19] and mares [20]. The increase in insulin and IGF-1 levels had a stimulatory effect on follicular growth (small follicle) before superovulation [21]. Insulin regulates CL function, through glucose availability and hormone production in cattle [22].

Our findings on the $5^{\text {th }}$ and $7^{\text {th }}$ days of treatments differ significantly $(p<0.05)$ between groups which are in agreement with the reports of Yelich et al. [23] in cow and Salazar-Ortiz et al. [20] in mare, who found that the concentrations of IGF-I in plasma are positively associated with body condition and nutrient intake of animals. Obese cows showed higher concentrations of IGF1 in plasma compared with 
lean cows [24]. Salazar-Ortiz et al. [20] also found that the number of follicles appeared to be significantly higher in the well-fed group mares as compared to restricted group. Our findings are also in agreement with the report of Velazquez et al. [24], who found that intraovarian application of IGF1 did not affect plasma IGF-1 concentrations in treated and control cow. The levels of IGF-I on the day of embryo recovery were far below as recorded by Velazquez et al. [25] in superovulated heifers and cows. In humans, serum concentrations of IGF-I did not allow the prediction of the ovarian response with regard to numbers of oocytes retrieved after superovulation [26]. However, other studies have indicated that plasma [27] concentrations of IGF-I increase during superovulatory treatments. The receptors for IGF-1 are present on uterus and embryo. It was also found that the polymorphism in IGF1R is associated with superovulation traits and indicated that the IGFIR gene can be used as a potential marker for donor selection in cattle [28]. Hence, the growth and development of embryos are affected by serum/plasma IGF-1 concentration.

\section{Conclusion}

Insulin administration during mid-luteal phase may be helpful in follicular and embryonic development through modulation of progesterone, insulin, and IGF-I in indigenous (B. indicus) Sahiwal embryo donor cows.

\section{Authors' Contributions}

The present study was part of SKS's Ph.D. thesis research. The work was designed by SP and HPG. SP and HPG guided, designed the research work, and drafted the final manuscript. The laboratory work was performed by SKS and SP. All authors read and approved the final manuscript.

\section{Acknowledgments}

The authors are very much grateful to the Dean, College of Veterinary and Animal Sciences and Joint Director IDF, Nagla, Pantnagar, Uttarakhand, India, for providing the facilities for conducting this experiment. The authors are also thankful to the Department of Science and Technology New Mehrauli Road, New Delhi - 110016 (Dy. No. C/3599/IFD/2014-15 dated 9/25/2014 and Dy. No. C/3801/IFD/2015-16 dated 11/4/2015), and Director Research Govind Ballabh Pant University of Agriculture and Technology, Pantnagar, India (Project no. 206), for providing necessary funds for this study.

\section{Competing Interests}

The authors declare that they have no competing interests.

\section{References}

1. Totey, S.M., Pawshe, C.H. and Rao, K.B.C. (1996) In vitro maturation of buffalo oocytes: Role of insulin and its interaction with gonadotrophins. J. Reprod. Fertil., 50(Suppl):
113-119.

2. Simpson, R.B., Chase, J.C.C., Spicer, L.J., Vernon, R.K., Hammond, A.C. and Rae, D.O. (1994) Effect of exogenous insulin on plasma and follicular insulin-like growth factor-I, insulin-like growth factor binding protein activity, follicular oestradiol and progesterone, and follicular growth in superovulated Angus and Brahman cows. J. Reprod. Fertil., 102(2): 483-492.

3. Damptey, J.K., Obese, F.Y., Aboagye, G.S. and Ayizanga, R.A. (2013) Correlations among concentrations of some metabolic hormones and nutritionally-related metabolites in beef cows. Online J. Anim. Feed Res., 3(4): 176-180.

4. Zhang, X., Davis, M.E., Moeller, S.J. and Ottobre, J.S. (2013) Effects of selection for blood serum IGF-I concentration on reproductive performance of female Angus beef cattle. J. Anim. Sci., 91(9): 4104-15.

5. Laxmi, N.A. and Sehgal, J.P. (2014) Relationship between plasma IGF I, body weight and age at puberty in low body weight Murrah calves and effect of supplementation of fermented yeast culture in the improvement of productive parameters. Int. J. Adv. Biotech. Res., 4(3): 369-373.

6. Mirzaei, M. and Rezaei, M. (2014) Blood Insulin-like growth factor-I (IGF-I) concentrations and some reproductive and physical characteristics of fat-tailed ewes and their litters during the breeding and non-breeding seasons. Revue Méd. Vét., 165(5-6): 144-149.

7. Kumar, A. and Laxmi, N.A. (2015) Role of IGF 1 in male and female reproduction in bovines: A review. Asia Pac. J. Res., 1(24): 17-25.

8. Francisco, C.C., Spicer, L.J. and Payton, M.E. (2003) Predicting cholesterol, progesterone, and days to ovulation using postpartum metabolic and endocrine measures. J. Dairy Sci., 86(9): 2852-63.

9. Snedecor, G.W. and Cochran, W.G. (1994) Statistical Method. $8^{\text {th }}$ ed. State University Press, Ames, Iowa. p503.

10. Pandey, N.K.J., Gupta, H.P., Prasad, S. and Sheetal, S.K. (2016) Plasma progesterone profile and conception rate following exogenous supplementation of gonadotropin-releasing hormone, human chorionic gonadotropin, and progesterone releasing intra-vaginal device in repeat-breeder crossbred cows. Vet. World, 9(6): 559-562.

11. Shukla, S.N., Agarwal, S.K., Shanker, U., Varshney, V.P. and Majumdar, A.C. (2005b) Modulation of ovarian response in anoestrus cattle treated with insulin alone and in combination with GnRH. Indian J. Anim. Reprod., 26(2): 159-164.

12. Gupta V.K., Shukla, S.N., Thakur, M.S. and Agrawal, R.G. (2011) Ovarian steroidal profile and fertility to insulin and $\mathrm{GnRH}$ administration in postpartum anestrus buffaloes, Indian J. Anim. Reprod., 32(2): 38-42.

13. Rivera, F.A., Mendonca, L.G.D., Lopes, G., Santos, J.E.P., Perez, R.V., Amstalden, M., Correa-Calderon, A. and Chebel, R.C. (2011) Reduced progesterone concentration during growth of the first follicular wave affects embryo quality but has no effect on embryo survival post transfer in lactating dairy cows. Reproduction, 141(3): 333-342.

14. Siddiqui, M.U., Panchal, M.T. and Kavani, F.S. (2011) Circulating ovarian steroids in relation to superovulatory response and embryo recovery in Sahiwal cows and heifers. Indian J. Anim. Reprod., 32(3): 12-16.

15. Alekseenko, A.N., Gavrikov, A.M., Maslev, T.S.I., Kardochev, M., Ralchev, I. and Lalev, I. (1989) The relationship between serum progesterone concentration and ovarian response in embryo donor cows. Zhivotnovdni Nanki, 26: 63-65.

16. Chauhan, F.S., Sarvaiya, N.P. and Mehta, V.M. (1995) Serum progesterone profile and its relationship with superovulatory response, in crossbred cows treated with PMSG. Indian J. Anim. Sci., 65(3): 289-292.

17. Selvaraju, S., Agarwal, S.K., Karche, S.D., Srivastava, S.K., Majmdar, A.C. and Shanker, U. (2002) Fertility responses and hormonal profiles in repeat breeding cows treated with insulin. Anim. Reprod. Sci., 73(3-4): 141-49. 
18. Souza, A.L., Galeati, G., Almeida, A.P., Arruda, I.J., Govoni, N., Freitas, V.J.F. and Rondina, D. (2008) Embryo production in superovulated goats treated with insulin before or after mating or by continuous propylene glycol supplementation. Reprod. Dom. Anim., 43(2): 218-221.

19. Gamarra, G., Ponsart, C., Lacaze, S., Le Guienne, B., Deloche, M.C., Monniaux, D. and Ponter, A. (2014a) Shortterm dietary propylene glycol supplementation affects circulating metabolic hormones, progesterone concentrations and follicular growth in dairy heifers. Livest. Sci., 162(4):240-251.

20. Salazar-Ortiz, J., Monget, P. and Guillaume, D. (2014) The influence of nutrition on the insulin-like growth factor system and the concentrations of growth hormone, glucose, insulin, gonadotropins and progesterone in ovarian follicular fluid and plasma from adult female horses (Equus caballus). Reprod. Biol. Endocrinol., 12(1): 72.

21. Ponsart, C., Gamarra, G., Lacaze, S. and Ponter, A.A. (2014) Nutritional status of donor cows: Insulin related strategies to enhance embryo development. Anim. Reprod., 11(3): 195-198.

22. Sousa, L.M.M., Silva, R.S., Neto, A.B., Cardoso, A.P.M. and Papa, P.C. (2016) Insulin and CL function: Lessons from studies in cattle and dogs. Anim. Reprod., 13(3): 373.

23. Yelich, J.V., Wettemann, R.P., Marston, T.T. and Spicer, L.J. (1996) Luteinising hormone, growth hormone, insulin-like growth factor-I, insulin and metabolites before puberty in heifers fed to gain at two rates. Domest. Anim. Endocrinol.,
13(4): 325-338.

24. Velazquez, M.A., Hadeler, K.G., Herrmann, D., Kues, W.A., Ulbrich, A., Meyer, H.H.D., Remy, B., Beckers, J.F., Sauerwein, H. and Niemann, H. (2011) In vivo oocyte developmental competence is reduced in lean but not in obese superovulated dairy cows after intraovarian administration of IGF1. Reproduction, 142(1): 41-52.

25. Velazquez, M.A., Newman, M., Christie, M.F., Cripps, P.J., Crowe, M.A., Smith, R.F. and Dobson, H. (2005) The usefulness of a single measurement of insulin-like growth factor- 1 as a predictor of embryo yield and pregnancy rates in a bovine MOET program. Theriogenology, 64(9): 1977-1994.

26. Keay, S.D., Liversedge, N.H., Akande, V.A., Mathur, R.S. and Jenkins, J.M. (2003) Serum IGF-1 concentrations following pituitary desensitization do not predict the ovarian response to gonadotrophin stimulation prior to IVF. Hum. Reprod., 18(9): 1797-1801.

27. Kuehner, L.F., Rieger, D., Walton, J.S., Zhao, X. and Johnson, W.H. (1993) The effect of a depot injection of recombinant bovine somatotropin on follicular development and embryo yield in superovulated Holstein heifers. Theriogenology, 40(5): 1003-1013.

28. Yang, W.C., Yang, L.G., Riaz, H., Tang, K.Q., Chen, L., Li, S.J. (2013) Effects in cattle of genetic variation within the IGF1R gene on the superovulation performance and pregnancy rates after embryo transfer. Anim. Reprod. Sci., 143(1-4): 24-9.

$* * * * * * * *$ 